\title{
Pleurotus sajor-caju and Pleurotus florida Mushrooms Improve Some Extent of the Antioxidant Systems in the Liver of Hypercholesterolemic Rats
}

\author{
Md. Asaduzzaman Khan ${ }^{1,3, *}$, Mohammad Mijanur Rahman², Mousumi Tania ${ }^{1,3}$ Md. Nazim Uddin ${ }^{1}$ \\ and Saleh Ahmed ${ }^{1}$ \\ ${ }^{I}$ National Mushroom Development and Extension Centre, Savar, Dhaka 1340, Bangladesh \\ ${ }^{2}$ Department of Biochemistry and Molecular Biology, Jahangirnagar University, Savar, Dhaka 1342, Bangladesh \\ ${ }^{3}$ Present address: Department of Biochemistry, School of Biological Science and Technology, Central South University, \\ Changsha, Hunan 410013, China
}

\begin{abstract}
Objectives: There is evidence that the antioxidant systems are imbalanced in hypercholesterolemic rats due to oxidative stress. Dietary supplementation of Pleurotus sajor-caju and P. florida are anti-hypercholesterolemic in rats. In this study, it was investigated whether these mushrooms have any effects on the antioxidant systems in hypercholesterolemic rat liver, which are altered.

Methods: Twenty young Long-Evans rats were randomly divided into 4 groups: control (fed basal diet), HC (fed $1 \%$ cholesterol with basal diet), $\mathrm{HC}+\mathrm{PS}$ (fed $5 \%$ P. sajor-caju powder with $1 \%$ cholesterol and basal diet) and $\mathrm{HC}+\mathrm{PF}$ (fed $5 \%$ P. florida powder with $1 \%$ cholesterol and basal diet). Rats were fed for 40 days, and then after sacrifice livers were collected, washed and homogenized. The content of reduced glutathione (GSH), thiobarbituric acid reactive substance (TBARS), and the activity of superoxide dismutase (SOD), catalase, glutathione peroxidase (GPx) in homogenate were measured.

Results: All the studied parameters were altered in hypercholesterolemic rats significantly in comparison with control group, except catalase (non-significant). Feeding of $P$. florida protected liver lipid peroxidation in hypercholesterolemic rat, as TBARS was significantly lower (by 34.5\%) in $\mathrm{HC}+\mathrm{PF}$ group than in HC group. Feeding of both mushrooms showed significant improvement in the activity of GPx in liver of hypercholesterolemic rats (in $\mathrm{HC}+\mathrm{PS}$ and $\mathrm{HC}+\mathrm{PF}$, the activity was higher by $50 \%$ and $80 \%$, respectively than in HC group). However, mushroom feeding showed no significant effect on GSH level, SOD and catalase activity in hypercholesterolemic rats.
\end{abstract}

Conclusion: This investigation confirms the antioxidant activities of $P$. sajor-caju and $P$. florida to some extent in hypercholesterolemic rats in addition to their anti-hypercholesterolemic activity.

Keywords: Pleurotus sajor-caju, Pleurotus florida, Hypercholesterolemic rats, Lipid peroxidation, Glutathione peroxidase, Supeoxide dismutase, Catalase, Glutathione.

\section{INTRODUCTION}

Hypercholesterolemia is one of the major complications in health of the people all over the world, which mainly contribute to cardiac diseases and hypertension. Hypercholesterolemia is also related to diabetes and it has role in inducing oxidative stress $[1,2]$. Oxidative stress is thought to contribute to the development of a wide range of diseases including Alzheimer's disease, Parkinson's disease, neurodegeneration, aging etc. and most importantly, cancers [3-5]. Since the ancient times, mushrooms have been regarded as important medicinal food items, which have preventing and protective effects against many disorders, including hypercholesterolemia. Several studies have proven the anti-

*Address correspondence to this author at the Department of Biochemistry, School of Biological Science and Technology, (172 Tongzipo Rd., Xiangya School of Medicine), Central South University, Changsha, Hunan 410013, P R China; Tel: 86-15243646146;

E-mail: asadkhanbmj@yahoo.com hypercholesterolemic effects of some edible mushroom species in experimental animals, and even in human [6-8]. One of the previous works of our related research group [9] also showed that dietary mushrooms of Pleurotus spp. have hypocholesterolemic effect on experimentally induced hypercholesterolemic rats.

Many species of mushrooms like Ganoderma lucidum, Lentinus edodes, Grifola frondosa, Cordyceps sinensis, and even some Pleurotus spp. like P. ostreatus have scientifically proved antioxidant activities [10-12]. This property of mushrooms is supposed to be effective also against the hypercholesterolemia induced oxidative alterations. Present study investigated the effect of dietary mushrooms Pleurotus sajor-caju and Pleurotus florida on the antioxidant systems (lipid peroxidation, reduced glutathione level, and antioxidant enzyme activities) of liver of hypercholesterolemic rats, as a continuation of the previous work of our laboratory [9]. However, P. ostreatus mushroom was excluded from this study, because its effects on the antioxidant system of 
hypercholesterolemic rats have already been well established [13]

\section{MATERIALS AND METHODS}

\section{Mushroom Sample}

The fruit bodies of $P$. sajor-caju and P. florida were collected from the production laboratory of National Mushroom Development and Extension Centre, Savar, Dhaka, Bangladesh. Mushrooms were then dried and crushed into powder, and mixed with basal diet to feed rats.

\section{Animal}

Twenty young Long-Evans rats (Rattus rattus) were taken for this study (of 95 $5 \mathrm{~g}$ of weight), and were randomly divided into four groups: control group (fed basal diet), HC group (fed 1\% cholesterol with basal diet), $\mathrm{HC}+\mathrm{PS}$ (fed $5 \%$ $P$. sajor-caju powder with $1 \%$ cholesterol and basal diet) and $\mathrm{HC}+\mathrm{PF}$ (fed $5 \% P$. florida powder with $1 \%$ cholesterol and basal diet). Rats were housed in an animal room at $23 \pm 2{ }^{0} \mathrm{C}$, under $12 \mathrm{~h}$ dark-light cycles. The composition of the orally fed basal diet was as follows $(\mathrm{g} / 100 \mathrm{~g})$ : wheat flour 50, rice powder 11, wheat bran 19, casein (non fat) 8 , egg white 10 , soybean oil 1 , table salt 0.5 , vitamin mixture 0.25 and mineral mixture 0.25 . The composition of the vitamin mixture in the diet was as follows $(\mathrm{g} / 100 \mathrm{~g}$ vitamin): retinyl acetate $9.5 \times 10^{-4}$, cholecalciferol $1.2 \times 10^{-3}, \alpha$-tochoferol acetate 0.05 , thiamin hydrochloride 2.4 , nicotinic acid 12 , riboflavin 2.4 , D-calcium pantothenate 9.6, pyridoxine hydrochloride 1.2, folic acid $9.5 \times 10^{-2}$, vitamin $\mathrm{K} 0.25$, cyanocobalamine $9.5 \times 10^{-3}$, inositol 47.95 and ascorbic acid 24.0. The composition of the mineral mixture added to diet was as follows (g/100 g minerals): calcium gluconate 28.5, $\mathrm{K}_{2} \mathrm{HPO}_{4}$ 17.3, $\mathrm{CaCO}_{3} 26, \mathrm{MgSO}_{4}$ 12.6, $\mathrm{KCl} 12.6, \mathrm{CuSO}_{4}$ 0.06, FeSO4 0.3, $\mathrm{MnSO}_{4} 0.55$, NaF $2.5 \times 10^{-4}$, KI $9 \times 10^{-4}$, sodium molybdate $3 \times 10^{-4}$, SeO $23 \times 10^{-4}$ and $\mathrm{CrSO}_{2} 1.5 \times 10^{-3}$. Rats were fed for 40 days and then sacrificed. Liver was collected and washed with phosphate buffer saline (PBS) and homogenized in PBS.

\section{Lipid Peroxidation Assay}

The level of the liver lipid peroxidation (LPO) was estimated according to the thiobarbituric acid reactive substrates (TBARS) test of Ohkawa et al. [14] with slight modification. The liver homogenate $(10 \%)$ was mixed with $0.02 \%$ butylhydroxytoluene to inhibit spontaneous oxidation. To each 50 $\mu \mathrm{l}$ of homogenate sample, $300 \mu \mathrm{l}$ of $8.1 \%$ sodium dodecyl sulphate, $2.0 \mathrm{ml}$ of $0.04 \%$ thiobarbituric acid in $20 \%$ acetic acid ( $\mathrm{pH} 3.5$ ) and $500 \mu \mathrm{l}$ distilled water were added. The mixture was then incubated at $95^{\circ} \mathrm{C}$ for $1 \mathrm{~h}$. After cooling with tap water, $1.0 \mathrm{ml}$ distilled water and $2.5 \mathrm{ml}$ of $15: 1(\mathrm{v} / \mathrm{v})$ n-butanol-pyridine were added, and the mixture was shaken vigorously for about $20 \mathrm{~min}$. After centrifugation at $1000 \times \mathrm{g}$ for $10 \mathrm{~min}$, the absorption of the upper organic layer was determined at $530 \mathrm{~nm}$ by spectrophotometer. TBARS of liver was determined as $\mathrm{nmol} / \mathrm{mg}$ protein.

\section{Protein Assay}

Protein was determined according to the method of Lowry et al. [15]. The rat liver homogenate was heated at 95 ${ }^{0} \mathrm{C}$ for about $60 \mathrm{~min}$ in $0.1 \mathrm{~N} \mathrm{NaOH}$ for complete dissolution of cellular proteins. After cooling, the lysate was reacted with alkaline copper reagent to produce protein- $\mathrm{Cu}^{++}$com- plex, which in turn reduced Folin reagent and produced blue colored complex. The absorption of the complex was measured against standard protein solution at $660 \mathrm{~nm}$. Bovine serum albumin (BSA) was used as positive control and distilled water as negative control in protein estimation.

\section{Glutathione Assay}

Reduced glutathione (GSH) was assayed according to the slight modified method of Moron et al. [16]. Briefly, $1 \mathrm{ml}$ of tissue homogenate was precipitated with $10 \%$ TCA (trichloro acetate), and centrifuged at $1000 \times \mathrm{g}$. To the aliquot of supernatant, $2 \mathrm{ml}$ of PBS and $0.5 \mathrm{ml}$ of DTNB (5,5'-dithio 2-nitro benzoic acid) were added and final volume was made $5 \mathrm{ml}$ with distilled water. The yellow colored product's optical density was measured at $412 \mathrm{~nm}$ by spectrophotometer. Commercial glutathione was used as standard. The level of $\mathrm{GSH}$ was expressed as $\mu \mathrm{g} / \mathrm{mg}$ protein.

\section{Superoxide Dismutase Assay}

Superoxide dismutase (SOD) activity was measured according to the slight modified method previously described by Marklund and Marklund [17]. Briefly, $500 \mu \mathrm{l}$ of tissue homogenate was added into the assay mixture containing $0.25 \mathrm{ml}$ absolute ethanol and $0.15 \mathrm{ml}$ chloroform. After 15 min of shaking the suspension was centrifuged (at $8000 \times \mathrm{g}$ for $2 \mathrm{~min}$ ) and supernatant was collected. The reaction mixture for auto-oxidation consisted of $2 \mathrm{ml}$ Tris- $\mathrm{HCl}$ buffer $(\mathrm{pH}$ 8.2 ), $0.5 \mathrm{ml} 2 \mathrm{mM}$ pyrogallol and $2 \mathrm{ml}$ of distilled water. The rate of auto-oxidation was measured in every $3 \mathrm{~min}$. This was considered as $100 \%$ auto-oxidation. The assay mixture for enzyme contained $2 \mathrm{ml}$ Tris- $\mathrm{HCl}$ buffer $(\mathrm{pH} 8.2), 0.5 \mathrm{ml}$ $2 \mathrm{mM}$ pyrogallol, $1.5 \mathrm{ml}$ of distilled water and $0.5 \mathrm{ml}$ of supernatant of tissue homogenate. This was immediately read at $470 \mathrm{~nm}$ every $3 \mathrm{~min}$ by a spectrophotometer. The activity of SOD was expressed as unit/ mg protein (one unit was the amount of enzyme that was utilized to inhibit $50 \%$ of autooxidation of pyrrogallol/ $\mathrm{min}$ ).

\section{Catalase Assay}

Catalase activity was measured according to slight modified method of Sinha [18]. Briefly, $100 \mu \mathrm{l}$ of tissue homogenate was added into the assay mixture containing 0.5 $\mathrm{ml} 0.2 \mathrm{M} \mathrm{H}_{2} \mathrm{O}_{2}, 1 \mathrm{ml}$ sodium phosphate buffer $(0.01 \mathrm{M}, \mathrm{pH}$ $7.0)$ and $0.4 \mathrm{ml}$ distilled water. Then $2 \mathrm{ml}$ of dichromateacetic acid was added after 15,30, 45 and $60 \mathrm{~s}$ to stop the reaction. The tubes were then heated for $10 \mathrm{~min}$ and allowed to cool; the green colored product's color intensity was measured at $570 \mathrm{~nm}$ by spectrophotometer. The activity of catalase was expressed as unit/ mg protein (one unit was the amount of enzyme that utilized $1 \mu \mathrm{mol}$ of $\mathrm{H}_{2} \mathrm{O}_{2} / \mathrm{min}$ ).

\section{Glutathione Peroxidase Assay}

The activity of Glutathione peroxidase (GPx) was determined according to slight modified method by Rotruck et al. [19]. Briefly, an assay mixture containing $0.5 \mathrm{ml}$ sodium phosphate buffer, $0.1 \mathrm{ml} 10 \mathrm{mM}$ sodium azide, $0.2 \mathrm{ml} 4 \mathrm{mM}$ $\mathrm{GSH}$ and $0.1 \mathrm{ml} 2.5 \mathrm{mM} \mathrm{H}_{2} \mathrm{O}_{2}$, was first prepared. To this, $100 \mu \mathrm{l}$ of homogenate sample were added, and the total volume was made $2.0 \mathrm{ml}$ with distilled water. This was incubated at $37{ }^{0} \mathrm{C}$ for $3 \mathrm{~min}$ and the reaction was finally terminated by adding $0.5 \mathrm{ml}$ of $10 \%$ TCA. After centrifugation $(1000 \times \mathrm{g}$ for $10 \mathrm{~min})$, the supernatant was obtained and 
$4.0 \mathrm{ml}$ of disodium hydrogen phosphate $(0.3 \mathrm{M})$ solution and $1.0 \mathrm{ml}$ of DTNB were added. The color intensity of the product was measured at $412 \mathrm{~nm}$ by spectrophotometer. Suitable aliquots of a standard (GSH) were also treated similarly. The enzyme activity was expressed as units/ mg protein (one unit was the amount of enzyme that converted 1 $\mu \mathrm{mol}$ of GSH to the oxidized form of glutathione (GSSH) in the presence of $\mathrm{H}_{2} \mathrm{O}_{2} / \mathrm{min}$ ).

\section{Statistical Analysis}

Data were analyzed and graphs were constructed by statistical program, SPSS-12.0 and Microsoft Excel. One way ANOVA and then post hoc tests were performed. $\mathrm{P} \leq 0.05$ was regarded statistically significant.

\section{RESULTS}

The effect of mushroom feeding on the liver GSH level of hypercholesterolemic rats was non-significant at $\mathrm{P} \leq 0.05$. The GSH was significantly lower in hypercholesterolemic group (HC) in comparison with the control group. Feeding of any of the $P$. sajor-caju and $P$. florida did not show any significant improvement in liver GSH level of hypercholesterolemic rats (Table $\mathbf{1}$ ).

The lipid peroxidation in the liver of hypercholesterolemic rats was significantly protected by $P$. florida feeding. The TBARS (product of LPO) content in the HC group was significantly higher than the control group. Feeding of $P$. florida controlled the LPO, as the TBARS was significantly lower in $\mathrm{HC}+\mathrm{PF}$ group than in HC group (by $34.5 \%$ ). However, the effect of $P$. sajor-caju was not significant at $\mathrm{P}$ $\leq 0.05$ (Table 1).

Fig. (1) presents the effect of mushroom feeding on the antioxidant enzyme activities in the liver of hypercholesterolemic rats. Liver SOD activity was significantly decreased in $\mathrm{HC}$ group rats in comparison with control group. Mushroom feeding had no significant improvement on this enzyme, i.e, the SOD activity varied statistically nonsignificantly among $\mathrm{HC}, \mathrm{HC}+\mathrm{PS}$ and $\mathrm{HC}+\mathrm{PF}$ groups. Also, the liver catalase activity varied non-significantly among the control and experimental groups. However, both mushroom feeding showed significant improvement in the activity of GPx in hypercholesterolemic rats. Cholesterol diet decreased the liver GPx activity in $\mathrm{HC}$ group than in control group. But in $\mathrm{HC}+\mathrm{PS}$ and $\mathrm{HC}+\mathrm{PF}$ group, the activity was found higher (by $50 \%$ and $80 \%$, respectively) which were statistically significant in comparison with HC group.

\section{DISCUSSION}

This study was performed to monitor the change of antioxidant activities in hypercholesterolemic rats and the effect a

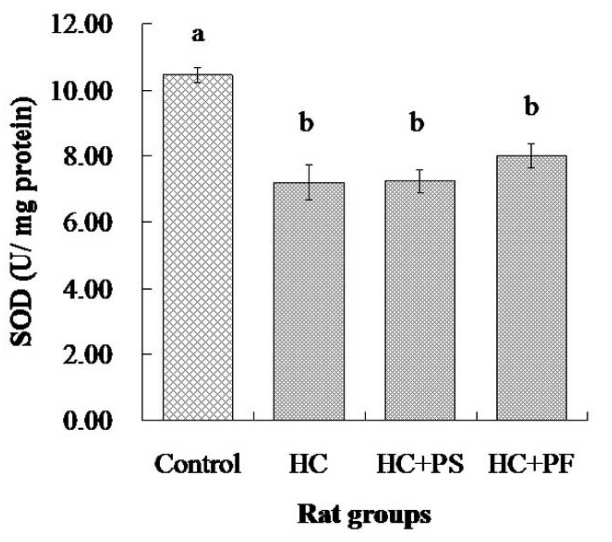

b

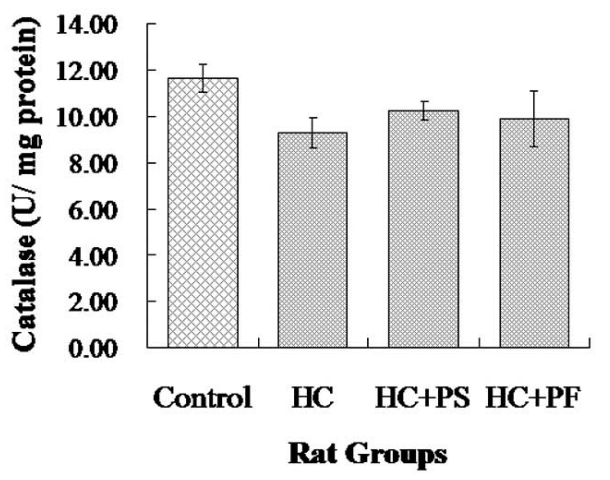

c

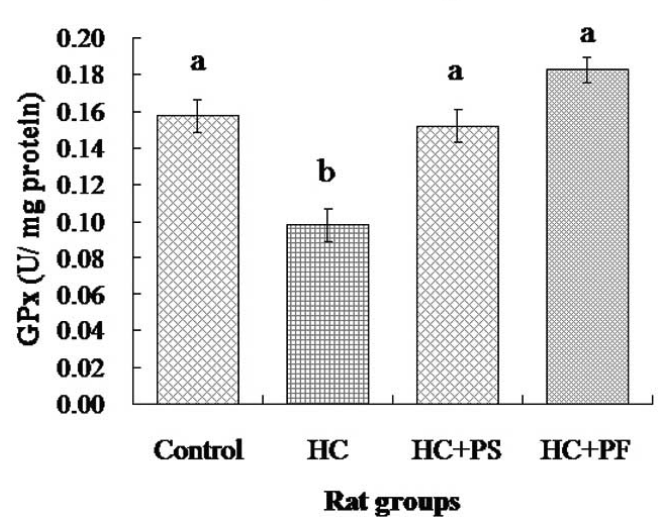

Fig. (1). Effect of Mushroom feeding on the antioxidant enzyme activities of hypercholesterolemic rats. Results (bars) are expressed as mean \pm SEM $(n=5)$. Bars in each figure with different letters are significantly different at $\mathrm{P} \leq 0.05$. Liver SOD (superoxide dismutase) activity was decreased in hypercholesterolemic rats in comparison with control group. Mushroom feeding had no significant effect on this enzyme. The liver catalase activity varied non-significantly among the groups. However, both mushroom feeding significantly increased the activity of GPx (glutathione peroxidase) in hypercholesterolemic rats, which was decreased.

Table 1. Effect of Mushroom Feeding on the Glutathione Level and Lipid Peroxidation in Liver of Hypercholesterolemic Rats

\begin{tabular}{|c|c|c|c|c|}
\hline & Control & $\mathrm{HC}$ & $\mathrm{HC}+\mathrm{PS}$ & $\mathrm{HC}+\mathrm{PF}$ \\
\hline $\mathrm{GSH}(\mu \mathrm{g} / \mathrm{mg}$ protein) & $9.53 \pm 0.48^{\mathrm{a}}$ & $7.16 \pm 0.76^{\mathrm{b}}$ & $7.56 \pm 0.69^{\mathrm{b}}$ & $7.44 \pm 0.64^{\mathrm{b}}$ \\
\hline
\end{tabular}

Results are expressed as mean \pm SEM (n=5). Values in a single row with different superscript are significantly different at $\mathrm{P} \leq 0.05$. HC- hypercholesterolemic rat group; HC+PS- $P$. sajor-caju fed hypercholesterolemic rat group; $\mathrm{HC}+\mathrm{PF}-P$. florida fed hypercholesterolemic rat group. 
of the mushrooms with hypercholesterolemic potential on the antioxidant systems. As, hypercholesterolemia induces cellular oxidative stress, to protect cells or tissues antioxidant systems have to fight against this. Due to hypercholesterolemia, the antioxidant systems are supposed to be altered usually $[1,2,8]$. In this study, it has been found that all the studied parameters (GSH, TBARS, SOD, GPx and catalase) were altered in the liver of hypercholesterolemic rats significantly, except catalase activity (catalase activity was lower in HC group than in control, but the difference was nonsignificant). These findings just support some previous studies, which showed the decrease in GSH level, and antioxidant enzyme activities [13] and increase in TBARS level [8] in hypercholesterolemic rat's liver in comparison with control normocholesterolemic rats. Feeding of P. sajor-caju and $P$. florida recovered the alterations in some degrees. It has been found that the TBARS was significantly lower in $P$. florida fed $\mathrm{HC}+\mathrm{PF}$ group than in $\mathrm{HC}$ group. And most importantly, both $P$. florida and $P$. sajor-caju fed groups $(\mathrm{HC}+\mathrm{PF}$ and $\mathrm{HC}+\mathrm{PS}$, respectively) had significantly higher GPx activity in liver. These findings suggest that these mushrooms are potential to recover and improve the alteration in antioxidant systems by hypercholesterolemia. The antioxidant activities of these mushrooms in lowering lipid peroxidation and increasing GPx activities may be due to their nutritional or chemical composition. Vitamin E is regarded as an important natural antioxidant, which has capability to protect lipid peroxidation. Pleurotus mushrooms contain a considerable amount of vitamin E [10]. Also, the enzyme GPx is involved in the protection of lipid peroxidation, of which cofactor is selenium (Se) [19]. Selenium is one of the important trace elements found in the fruiting bodies of P. florida and P. sajor-caju [20].

In this study, for the first time the antioxidant activity of these two mushrooms in hypercholesterolemic rats is being reported, at least to some extent. The antioxidant activities of $P$. ostreatus and some other mushrooms have been reported earlier [10-12, 21]. Also a few reports exist about the antioxidant and antitumor role of $P$. florida [22]. But the report about the antioxidant potential of $P$. sajor-caju is rare. $P$. sajor-caju is nutritionally rich with higher protein $[20,23]$ than other Pleurotus mushrooms, and it has significant hypocholesterolemic effects [9]. So, this mushroom is recommended for the common people as a nutritious and health beneficial food supplement. The findings of this study suggest that in addition to nutritional and hypocholesterolemic importance, both $P$. florida and $P$. sajor-caju have roles in recovering and improvement of antioxidant systems of hypercholesterolemic rat liver at least in some degrees.

\section{CONCLUSION}

It is well established that $P$. florida and $P$. sajor-caju have significant health benefits through the modulation of physiological functions that include various atherogenic lipids in hypercholesterolemia. Also, these mushrooms are nutritionally rich food items. The findings of this study confirm the antioxidant activities of these mushrooms in hypercholesterolemic rats in addition to their hypocholesterolemic activity, at least to some extent. It is suggested to regular intake of these mushrooms to protect hypercholesterolemic condition and oxidative stress. More research are recom- mended on the investigation of antioxidant activities of the extracts or powder of the fruiting bodies of $P$. florida and $P$. sajor-caju on different human cell lines, animal model and human subjects.

\section{ACKNOWLEDGMENT}

This study was supported by the Strengthening Mushroom Development project of Ministry of Agriculture, People's Republic of Bangladesh.

\section{REFERENCES}

[1] Bhatnagar D, Soran H, Durrington PN. Hypercholesterolaemia and its management. BMJ 2008; 337: a993.

[2] Chenni A, Yahia DA, Boukortt FO, Prost J, Lacaille-Dubois MA, Bouchenak M. Effect of aqueous extract of Ajuga iva supplementation on plasma lipid profile and tissue antioxidant status in rats fed a high-cholesterol diet. J Ethnopharmacol 2007; 109(2): 207-13.

[3] Nunomura A, Castellani R, Zhu X, Moreira P, Perry G, Smith M. Involvement of oxidative stress in Alzheimer disease. J Neuropathol Exp Neurol 2006; 65(7): 631-41.

[4] Wood-Kaczmar A, Gandhi S, Wood N. Understanding the molecular causes of Parkinson's disease. Trends Mol Med 2006; 12(11): 521-8.

[5] Khan MA, Tania M, Zhang DZ, Chen HC. Antioxidant enzymes and cancer. Chin J Cancer Res 2010; 22(2): 87-92.

[6] Cochran KW. Medical effects. In: Chang ST, Hayes WA, Eds. The Biology and Cultivation of Edible Mushrooms. New York. Academic Press Inc. 1978; pp. 169-86.

[7] Koh JH, Kim JM, Chang UJ, Suh HJ. Hypocholesterolemic effect of hot-water extract from mycelia of Cordyceps sinensis. Biol Pharm Bull 2003; 26(1): 84-7.

[8] Hossain S, Hashimoto M, Choudhury EK, et al. Dietary mushroom (Pleurotus ostreatus) ameliorates atherogenic lipid in hypercholesterolaemic rats. Clin Exp Pharmacol Physiol 2003; 30(7): 470-5.

[9] Alam N, Amin R, Khan A, et al. Comparative effects of oyster mushrooms on lipid profile, liver and kidney function in hypercholesterolemic rats. Mycobiology 2009; 37(1): 37-42.

[10] Kaul TN. Biology and Conservation of mushrooms. Oxford \& IBH Publishing Co. Pvt. Ltd. New Delhi. India. 2001; pp. 117-45.

[11] Zhang Y, Mills GL, Nair MG. Cyclooxygenase inhibitory and antioxidant compounds from the mycelia of the edible mushroom Grifola frondosa. J Agric Food Chem 2002; 50(26): 7581-5.

[12] Khan MA, Tania M, Zhang DZ, Chen HC. Cordyceps Mushroom: A potent anticancer nutraceutical. Open Nutra J 2010; 3: 179-83.

[13] Bobek P, Ozdin L, Kuniak LE. Effect of oyster mushroom and isolated $\beta$-glucan on lipid peroxidation and on the activities of antioxidative enzymes in rats fed the cholesterol diet. J Nutr Biochem 1997; 8: 349-71.

[14] Ohkawa H, Orishi N, Yagi K. Assay for lipid peroxides in animal tissues by thiobarbituric acid reaction. Anal Biochem 1979; 95 (2): 351-8.

[15] Lowry OH, Rosebrough NJ, Far AL, Randall RJ. Protein measurement with the Folin phenol reagent. J Biol Chem 1951; 193(1): 265-75.

[16] Moron MS, Depierre JW, Mannervik B. Levels of glutathione, glutathione reductase and glutathione S-transferase activities in rat lung and liver. Biochim Biophys Acta 1979; 582(1): 67-78.

[17] Marklund S, Marklund G. SOD activity assay by the method of pyrogallol. Eur J Gerontol 1974; 17: 429-37.

[18] Sinha AK. Colorimetric assay of catalase. Anal Biochem 1972; 47: 389-94.

[19] Rotruck JT, Pope AL, Ganther HE, Swanson AB, Hafeman DG, Hoekstra WG. Selenium: biochemical role as a component of glutathione peroxidase. Science 1973; 179(73): 588-90.

[20] Alam N, Amin R, Khan A, et al. Nutritional Analysis of Cultivated Mushrooms in Bangladesh- Pleurotus ostreatus, Pleurotus 
sajor-caju, Pleurotus florida and Calocybe indica. Mycobiology 2008; 36(4): 228-32.

[21] Jayakumar T, Sakthivel M, Thomas PA, Geraldine P. Pleurotus ostreatus, an oyster mushroom, decreases the oxidative stress induced by carbon tetrachloride in rat kidneys, heart and brain. Chem Biol Interact 2008; 176(2-3): 108-20.
[22] Manpreet K, Giridhar S, Khanna PK. In vitro and in vivo antioxidant potentials of Pleurotus florida in experimental animals. Mushroom Res 2004; 13(1): 21-6.

[23] Khan MA, Khan LA, Hossain MS, Tania M, Uddin MN. Investigation on the Nutritional Composition of the common Edible and Medicinal Mushrooms Cultivated in Bangladesh. Bangladesh J Mushroom 2009; 3(1): 21-8.

Received: January 05, 2011

Revised: January 27, 2011

Accepted: January 28, 2011

(C) Khan et al.; Licensee Bentham Open.

This is an open access article licensed under the terms of the Creative Commons Attribution Non-Commercial License (http://creativecommons. org/licenses/ by-nc/3. 0/) which permits unrestricted, non-commercial use, distribution and reproduction in any medium, provided the work is properly cited. 